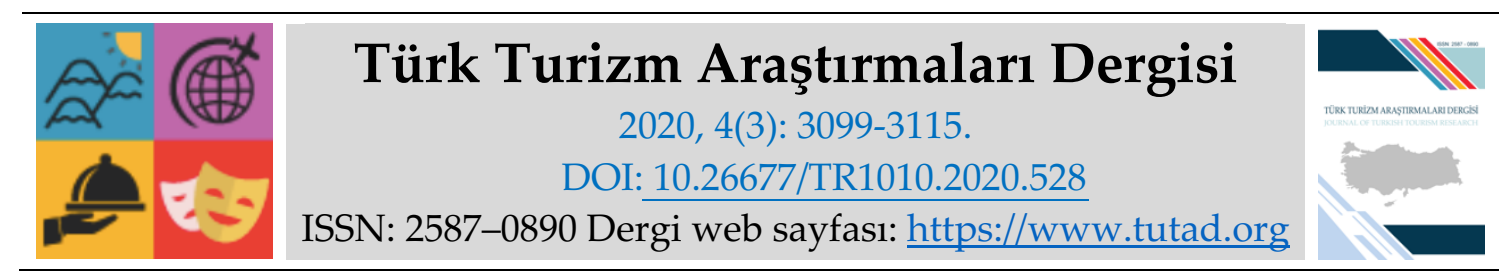

KAVRAMSAL MAKALE

\title{
Gastronomi Trendlerinden Biri Olarak Terapötik Beslenme ve Hıltlar Teorisi
}

Doç. Dr. Duran CANKÜL, Eskişehir Osmangazi Üniversitesi, Turizm Fakültesi, Eskişehir, eposta: durancankul@hotmail.com

ORCID: https://orcid.org/0000-0001-5067-6904

Hilal AYVALI, Yüksek Lisans Öğrencisi, Eskişehir Osmangazi Üniversitesi, Sosyal Bilimler Enstitüsü, Eskişehir, e-posta: hkayvalı@gmail.com

ORCID: https://orcid.org/0000-0002-1127-0001

Öz

$\mathrm{Bu}$ araştırmada günümüz Gastronomi trendlerinden terapötik beslenmenin Anadolu ve Osmanlı Mutfağı'ndaki karşıllı̆ı Hiltlar Teorisi'ne göre beslenmenin unsurlarını, yoğun olarak 15. ve 17. yy. arası olmak üzere yüzyıllardır uygulanış biçimini, Müslüman tabiplerce oluşturulan reçetelerin prensiplerini akademi ile sektöre arz edebilmek amaçlanmaktadır. Bu amaç doğrultusunda araştırmada nitel araştırma tekniklerinden doküman analizi kullanılmıştır. Doküman analizi aracıllğg ile Hiltlar teorisini geliştiren ve üzerine çok fazla çalışmalar yapan İbn Sina'nın $(980$ - 1037) kendisi, öğrencileri ve ekolünden gelen hekimler, düşünürler tarafından fikirlerinin ve uygulamalarının kaydedildiği, günümüzde ulaşılabilen el yazması eserler ve diğer basılı kaynaklar incelenmiş ve analiz edilmiştir. Elde edilen verilerin önemli kısmı Arapça, İbranice ve Osmanlıca yazılmış olduğundan araştırmacılar tarafından günümüz Türkçesine çevrilerek incelenmiştir. Analiz sonuçları; mizacı dengede tutup akli, zihni, bedeni dengeyi sağlayarak, her açıdan sağlıklı bir yaşam yaşanmasının mümkün olduğunu savunan Hıltlar teorisinin, günümüzde birçok besini aynı anda, karıştırarak tüketen insanın bozulan dengesini ve sağlığını yeniden düzeltmede, reçete düzenleme ve oluşturmada önemli bir kaynak olduğunu göstermektedir.

Anahtar Kelimeler: Hıltlar Teorisi, İbn Sina Gıda Reçeteleri, Terapötik Beslenme, Gastronomi. Makale Gönderme Tarihi: 24.05.2020

Makale Kabul Tarihi: 06.07.2020

\section{Önerilen Atıf:}

Cankül, D. ve Ayvalı, H. (2020). Gastronomi Trendlerinden Biri Olarak Terapötik Beslenme ve Hiltlar Teorisi, Türk Turizm Araştırmaları Dergisi, 4(3): 3099-3115.

(c) 2020 Türk Turizm Araştırmaları Dergisi. 


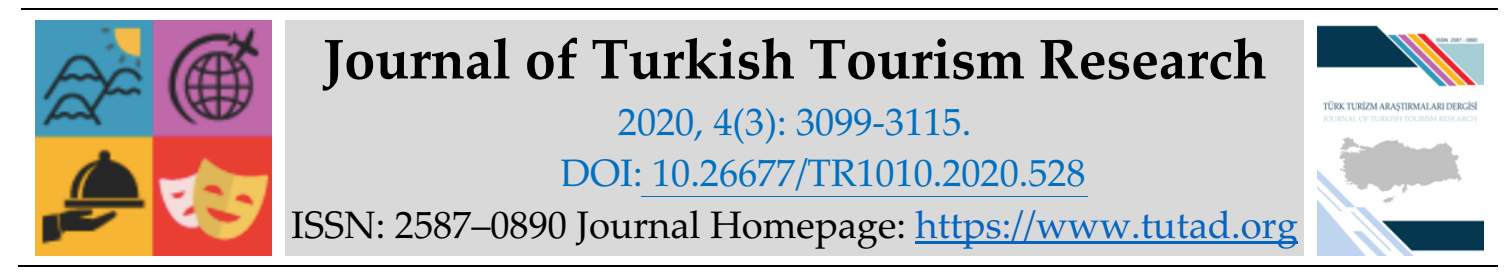

\title{
CONCEPTUAL PAPER
}

\section{Therapeutic Nutrition and Hilts Theory as One of The Gastronomy Trends}

Associate Prof. Dr. Duran CANKÜL, Eskişehir Osmangazi University, Faculty of Tourism, Eskişehir, e-mail: durancankul@hotmail.com ORCID: https://orcid.org/0000-0001-5067-6904

Hilal AYVALI, MSc. Student, Eskişehir Osmangazi University, Social Sciences Institute, Eskişehir, e-mail: hkayvalı@gmail.com ORCID: https://orcid.org/0000-0002-1127-0001

\begin{abstract}
In this research, it is aimed to present the elements of the therapeutic nutrition according to the Hilts Theory which is one of the current Gastronomy trends in Anatolia and Ottoman Cuisine, the way of application for centuries intensely in 15th and 17th centuries, and the principles of prescriptions created by Muslim physicians to the academy and the sector. For this purpose, document analysis, one of the qualitative research techniques, was used in the research. Ibn Sina (980 - 1037), who developed the Hilts Theory and made a lot of work on it, was examined and analyzed through document analysis, where manuscripts and other printed sources, whose ideas and practices were recorded, can be reached today. Since most of the data obtained was written in Arabic, Hebrew and Ottoman Turkish, it was translated by researchers into Turkish today. The results of the analysis suggest that the Hilts Theory, which proposes that it is possible to live a healthy life in all respects by keeping the temperament in balance and providing balance of mind, mind and body, is an important source in correcting the deteriorated balance and health of the people who consume many foods at the same time and editing and creating prescriptions.
\end{abstract}

Keywords: Hilts Theory, Ibn Sina Food Prescriptions, Therapeutic Nutrition, Gastronomy.

Received: 24.05 .2020

Accepted: 06.07.2020

\section{Suggested Citation:}

Cankül, D. and Ayvalı, H. (2020). Therapeutic Nutrition and Hilts Theory as One of The Gastronomy Trends, Journal of Turkish Tourism Research, 4(3): 3099-3115.

(C) 2020 Türk Turizm Araştırmaları Dergisi. 


\section{Gíriş}

Terapötik kelimesi; terapiye ait olan, terapi de tedavi edici anlamına gelen Fransızca kökenli sözcüklerdir (TDK, 2020). Terapötik gıda; tıbbi beslenme başlı̆ğ altında incelenen ve gıdaların tedavi edici biçimde, ilaç olarak kullanılmasına verilen isimdir.

Sağlığa yahut şifaya yönelik beslenme yaklaşımı günümüzde popüler bir yaklaşım olsa da bilhassa 15. ve 17. yy. arasında, Kanuni Sultan Süleyman'ın hükümdarlığında Matbah - 1 Amire'nin (mutfağın) Helvahane bölümüne dahledilen hekimlerle, Osmanlı Mutfağı beslenme anlayışının ve reçete uygulamalarının temel amacını oluşturmuştur. Helvahane; ismi Matbah - 1 Amire olan Osmanlı saray mutfağının son bölümüdür. Bu bölüm tatlıların, şerbetlerin, turşuların, pestillerin, macunların, helvaların ve de mutfağın eczanesi takdiriyle anılma sebebi olan, hapların, şurupların, ilaçların hazırlandığı bölümdür (Oğuz, 2015).

Ortaçağ tıbbının bilgeliğiyle dertlerine şifa arayan Osmanlı, hastalıklarına devayı baharatlarda, hayvan yağlarında, bitkilerde, meyvelerde, itırlı nebatatta ve bu hammaddelerden üretilen dalıklarda (hapın Osmanlı'daki ve hatta Orta Asya Türkçesi'ndeki ismi, Çelebioğlu, 1963) aramıştır (Binbaşı Hüseyin Bey, 1874; Demirhan, 1975, 2001). Osmanlı'nın devayı yemekte arama davranışı, Helvahane'den, Matbah - 1 Amire'den ve hatta Osmanlıdan da evvele dayanmaktadır. Ardında yüzyıllar öncesinin tabiplerinin ve feylesoflarının bilgeliğini taşıyan bu davranış, İslam tababetinin ve İslami diyetin temeli olan şifa için, şifa niyetine beslenme mirasından kaynaklanmaktadır. (Rahman, 1997; İbn Sina, 2004, 2006; Nidai, 1507). Bu mirasın kaynağının temsilcileri Müslüman feylesoflardan Farabi, Müslüman tabipler için Kındi, İbn Sina'dır ve elbette bu iki hekimin incelediği hekimlerden Hipokrat, Galen, hekimlerin de diktelerini geliştirmelerini sağlayan feylesoflardan; Aristo, Empidokles, Pisagor gibi Klasik Dönem Feylesoflarıdır (Arıkan, 2010; Hamarneh, 1973; Kuşkonmaz, 2016; Levey, 1966; Metler, 1947). İbn Sina'nın bütünsel şifa maksadıyla geliştirdiği Hılt - mizaç temelli beslenme teorisinde en mühim vurgu hastalık ile şifanın diyetler ve yeme - içme reçetelerinde gizli olduğu bilgisine yapılmıştır.

Araştırmanın konusu tıp - felsefe tarihi ve tıbbi bilgilerle yüklü olmasına rağmen yemek reçetelerinin tasnifi, besin sınıflaması, pişirim teknikleri tamamı ile gastronomi araştırmalarının alanına girmektedir. Osmanlı Mutfağı reçetelerinde sıklıkla karşılaşılan damla sakızı ilaveli pilavlar, her pilavın farklı bir hoşabla (hoş su) ikramı, meyvelerle etlerin bir arada pişirilmesi, kimi ekmeklere maya eklenirken kimine eklenmemesi, aynı reçetelerin yaz ve kış mevsimlerinde farklı uygulanmaları, her padişahın mizaç incelemelerine göre reçete tatbikleri ve daha birçok örnek bu teorinin eseridir. Dolayısıyla İbn Sina'nın beslenmeye dayalı şifa vurgusunda gastronomlar ve gastronomiyle ilgilenenlerin önemsemesi gereken kısım; gıdaların özelliklerinin açıklanarak tasnif edildiği, 15. yy. ünlü hekimi, Osmanlı'dan günümüze ulaşan birçok yemek reçetesinin mimarı, İbn Sina ekolünün takipçisi Muhammed Bin Mahmud Şirvani'nin, İbn Sina'nın tasnifine dayanarak besinlerin sınıflandırıldığı ve reçete oluşturduğu kısımdır. Sınıflandırma detaylı incelendiğinde, yemek reçetelerinde besinlerin bir araya getirilme ve uygulanan pişirilme tekniklerinin nedenleri, bilvasita da reçetelerin oluşturulma prensipleri anlaşılmaktadır. Araştırmada günümüz gastronomi eğilimlerinden terapötik beslenmenin Anadolu ve Osmanlı Mutfağı'ndaki karşıllı̆ı Hıltlar Teorisi'ne göre beslenme unsurlarını, yoğun olarak 15. ve 17. yy. arası olmak üzere yüzyıllardır uygulanış biçimini, Müslüman tabiplerce oluşturulan reçeteleri nedensel perspektifle akademi ile sektöre arz edebilmek ve bu bilgilerin günümüze aktarılmasıyla geçmişin bilgeliğinden fayda sağlayabilmek amaçlanmaktadır. 


\section{KAVRAMSAL ÇERÇEVE}

Araştırma İbn Sina gibi birçok alanda kitaplar, risaleler, eserler vermiş bir ilim insanına dayandığından, İbn Sina ile merbut yüzyıllarca yazılmış, aktarılmış birçok kaynak mevcuttur. Bu çalışma İ̉n Sina'yı Gastronomi alanına sağladığı faydalar ve reçeteler yönüyle incelediği için hassaten besin tasniflerine mensup kaynaklar ele alınmıştır.

Ortaçağ Tıbbi ile beraber Meşşai geleneğin en güçlü temsilcilerinden olan İbn Sina, Hiltlar teorisinin ortaya çıkış sürecinde başta Klasik Dönem Yunan Filozofları olmak üzere hekim Kindi, feylesof Farabi gibi mühim isimleri analiz ederek, ylllar boyu süren tahliller, okumalar gerçekleştirmiş, edindiği bilgileri kendi yaklaşımıyla, meşşai gelenek içerisinde sentezleyerek diktelerini oluşturmuştur. Meşşai gelenek; Aristo'nun öğrencilerine ders verirken zihin ve bedeni aynı anda çalıştırmak amacıyla açık havada yürüyerek ders anlatmasından ortaya çıkan ve zihin - beden bütünlüğünü vurgulayan bir öğretim tekniğidir. Bu geleneğe dahil olan öğreticiler Aristo mantığını temel edinerek zihnin açıklığının, doğru çalışmasının aktif bedenle mümkün olabileceğini ikrar etmiştir (Kindi, 1999; Macit, 2006).

Farabi'nin Aristo çevirilerini ve analizlerini inceleyene değin beslenme ile ilgili çalışması bulunmayan Sina, Farabi tahliliyle beraber zihnin aktifliğinin bedenle, bedenin aktif kalabilmesinin de beslenmekle yakın ilişkisi olduğunu idrak etmiştir (Özturan, 2014). Bu bilgiler ışığında İbn Sina Hıltlar teorisi başta olmak üzere tüm alan (tıp, matematik, felsefe gibi) çalışmalarında dikkatini beşerin açı zihinle, verimli bir yaşam sürmesine yoğunlaştırmıştır. Sina'ya göre verimli beşer; Kuran'da bahsi geçen apaçık zihinli, ilimle, adaletle, fayda sağlayarak, üreterek var olan beşerdir ve verimli yaşam da bu insan formunun var olduğu yaşamdır (İbn Sina, 2004, 2006).

İnsanın değişken bir varlık olduğunun farkında olan İbn Sina değişimin sebeplerini araştırarak beşeri dengeden uzaklaştıran unsurların özellikle beslenme reçetelerinde gizlendiğini belirlemiş ve dengesizliğe mahal vermemek amacıyla mizaçlar çalışmasını geliştirmiştir. (Durusoy, 1997). Beşerin temiz zihin, temiz beden, temiz akıl ve temiz bilinçle var olmasını amaçlayan Sina, evreni, var oluşu, nisyan (unutmuş) olan insanı anlamayı hedeflediğinden uzun yıllar Aristo, Pisagor, Empidokles, Hipokrat, Kindi, Farabi gibi filozofları tahlil ederek Farabi mantık ekolüyle Hümoral Patolojiyi veya İslam tababetindeki adıyla Ahlat-1 Erbaayı; (dört ahlat, dört latif sıvı, dört sıvı, dört usare) filvaki tıp ilmiyle beraber yemek reçetelerinin mihenk taşını oluşturmuştur (Rahman, 1997).

Besinlerin özellikleri ile beraber insan vücuduna farklı mevsimlerde farklı tesirleri olduğunu savunan Sina ve mukaddem tabipler insanın tabiatını "hılt" adı verdikleri dört ana gruba ayırmıştır (İbn Sina, 2017a). Dört hıltın her insanda bir diğerinden farklı içerikte bir araya gelerek kişiye özel oluşturduğu hususi dengeye, hilt dengesinden kaynaklanan ruhsal, bedensel, zihinsel tüm özelliklerinin fevki toplamına mizaç denmiştir (Rahman, 1997). Ateş, hava, toprak ve su, dört ana unsur anlamına gelen anasır-1 erbaa şeklinde adlandırılmış, dört elementin insan bedenindeki karşılığı kabul edilen dört sıvıya da ahlat-1 erbaa, dört hıtl adı verilmiştir (Anawati, 1950; İbn-i Sina, 2009, 2017c,). Bu sivılar; ateş (sarı safra) - sıcak ve kuru, toprak (sevda) - soğuk ve kuru, su (balgam) - soğuk ve nemli, hava (kan) - sıcak ve nemli besinler şeklinde kategorize edilmiştir. Teoriye göre her insanda baskın olan bir sıvı dört mizaçtan üst - ana mizacı oluşturmuştur, Ahlat-ı erbaa prensibine göre dört temel mizaç; demevi (kan), safravi (ateş), balgami (su) ve sevdavi (toprak) mizaçtır.

Dört hılt teorisinin temelinde Aristo'nun "Evrene dörtlü ritim hakimdir, canlı ve cansız her şeyin yapısı hava, ateş, toprak, su olan dört ana elementten oluşmaktadır" diktesi yer almaktadır (Aristo, 1935; Bedevi, 1977; İbn Sina, 1978). 
Aristo'nun bu fikri temellendirirken dayanak noktası, fikirlerinden etkilendiği, element gerçeğini ilk defa ortaya koyan ve günümüze de ulaşmış olan şiirlerinin yer aldığı Tabiat Üzerine adlı eseriyle Empidokles'tir (M.Ö. 492 - 432), (Aristo, 2017). Empidokles, Pisagor'un (M.Ö. 570 - 495) mükemmel, Tanrısal güç olarak nitelendirdiği dört sayısına atfen dört elementi tabiatın mükemmel gerçekliği olarak kuramlaştırmıştır (Arslan, 2008). Tıbbın kurucusu kabul edilen Hipokrat (M.Ö. 460 - 377), Aristo'nun (M.Ö. 384 - 322) "dörtlü ritim" fikrinin üzerine inşa ettiği teorisinde dört elementi tıbba uyarlayarak tıbbi beslenmenin, beslenmenin şifayla neticelenmesi düşüncesinin temelini atmıştır (Hipokrat, 2018; Daremberg ve Martiniere, 1962). Sonrasında Galen başta olmak üzere başka tabiplerce de geliştirilen teori İbn-i Sina'nın El Kanun-i Fi't Tıp (İbn Sina, 2017 a, b, c, d) eseriyle zirveye taşınarak 16.yy sonuna kadar Avrupa'da da en önemli tıp eseri olarak okutulmuştur (Corbin, 1980, 1986; Goichon, 2004).

Teorinin üç güçlü ismi Hipokrat, Galen ve İbn Sina'nın teoriye katkılarını ve teorinin gelişim sürecini inceleyecek olursak; Hipokrat öncesinde hastalıkların ilahiler tarafından cezalandırma şekli olduğunu inananlara Hipokrat hastalıkların bir ceza olmadığını, besinlerin şifa veya hastalık getirdiğini, hastalıkların tedavi edilebileceğini, ilaçları öğretmiş, dört sıvı kuramıyla bilimsel tıbbın temelini atmıştır. 500 sene sonra gelen Galen Hıltlar teorisini geliştirmiş, kötü beslenme ile bedendeki sıvıların soğuyarak dengeyi bozduğunu, baharat desteği ile hastanın 1sıtılarak iyileştirilmesi gerektiğini salık vermiştir. 1000 sene sonra doğan İbn Sina ise teoriyi evvela hastalıkları inceleyerek uygulamış sonrasında ise hastaları inceleyerek geliştirmiştir. Besinleri, organları mizaçlarına yönelik sınıflamış ve bu sınıflamaya yönelik beslenme önerileri getirmiştir. (Daremberg ve Martiniere, 1962; Hamarneh, 1963; Kuşkonmaz, 2016). Teorinin yemek reçetelerine mefkuresi, literatüre "Büyük Osmanlı hekimi" olarak geçen Muhammed Bin Mahmud Şirvani'nin çabasıdır. İbn Sina'nın önerilerini yüzlerce yıl sonra takip etmeye devam eden, Osmanlı'da yaşamış, 15. yy. hekimlerinden Muhammed Bin Mahmud Şirvani Hıltlar Teorisi'ne mutabık yemek reçetelerini koruyucu hekimlik maksadıyla geliştirmiştir (Akpınar ve Harmanc1, 2009).

Tıp ile şifa başta olmak üzere felsefe, varlık, matematik alanlarında da mühim çalışmalar barındıran İbn Sina'nın eserlerinden Gastronomiyi ilgilendiren ve gida tasnifiyle ilgili bilgiler içerenleri şunlardır:

El Kanun -i Fi't Tib: İbn Sînâ'nın tıp ve şifa konusundaki en önemli eseri olan El Kanun -i Fi't Tıp muhteviyatında basit ve mürekkep ilâçları, hastalıkları, hastalıkların şifalarını barındıran, beş bölümde kaydedilmiş bir iyileşme eseridir. 1593'te Roma'da ilk defa basılan eser, daha sonra Kahire (1290), Bulak (1294), Leknev (1298) ve Lahor (1905) gibi farklı coğrafyalarda yayımlanmıştır. Gerard de Cremone tarafından Latince'ye çevrilen nüshası 1473'te Milano'da, 1279 'da Roma'da gerçekleştirilen İbrânîce tercümesi ise 1491'de Napoli'de basılmıştır. Ayrıca Tokatlı Mustafa Efendi tarafından yirmi bir cilt halinde Türkçe'ye çevrilmiştir (Tokatlı Hekim Mustafa, 2009).

El - Mebde' ve'l - Me 'Ad: Ahlak ve metafiziğin açıklandı̆̆ı̆, üç bölümden oluşan eserin ilk bölümünde varlık, varlığın doğrulaması, ikinci bölümde varlıkların vahdet ile sentezi, alem Tanrı ekseni, üçüncü bölümde nefs, mutluluk, lezzet, hakikat kavramları yer almaktadır. Nefs lezzet bölümünde şifaya dolayısıyla beslenmeye atıflarda bulunulmuştur. Eser Abdullah Nûrânî tarafından 1984'te, Tahran'da yayımlanmıştır (İbn Sina, 1984).

En-Necât: İbn Sina, eserlerinde genellikle bir öncekine atıf ve doğrulamalarda bulunduğundan En Necat eseri de Eş - Şifâ' 'n mantık, doğa ve ilahiyat kısımlarının telhisi gibidir. İlk defa 1593'te Roma'da İbn Sînâ'nın yazdığı haliyle basılan kitap, 1952' de yayımlanan Fazlur Rahman'ın doktora tezinin konusu olmuştur (Rahman, 1952). 
Günümüzde el yazması bölümlerin mevcut olduğu kitap Süryânîce, İbrânîce, Latince, Farsça, İngilizce, Almanca, İspanyolca ve Fransızca'ya çevrilmiştir.

El - Urcûze Fi'ț Tıb: El Kanun - i Fi't Tıbbın telhisi olan eser, Sina'nın öğrencilerine bilgilerini kolaylıkla anlayabilmeleri için urcuze tekniğiyle yazılmuştır. Bilgilerin kolaylıkla zihinde tutulması amacıyla "urcûze" geleneğine uygun olarak nazmedilmiş, nazım halinde düzenlenmiştir. Ayasofya Müzesi, İstanbul Üniversitesi Kütüphanesi ve Süleymaniye Kütüphanesi'nde eserin el yazması nüshaları mevcuttur.

Eş - Şifa: İlk olarak 1952 - 1983 yılları arasında, Kahire' de İbrâhim Medkûr tarafından yirmi iki cilt halinde yayımlanan eser Türkçe, Süryanice, Latince, Farsça, İngilizce, Rusça, Fransızca, Almanca, İspanyolca gibi birçok dile çevrilmiş ve eserin çeşitli bölümleri için özet, açıklama ve yorumlar yazılmıştır (Anawati, 1950; Altıntaş, 1985; Janssens, 1991). İsminden de anlaşıldığ üzere eser; şifa, besinlerin özellikleri, hıltlar ve mizaçlar üzerine kaleme alınmıştır.

İşarat ve Tenbihat: Eser İbn Sina tarafından felsefenin mütearifelerinin açıklanması amacıyla kaleme alınmıştır. Mantık, fizik ve metafizik bölümleri şeklinde üç bölümle seyreden eserin ilk bölümünde mantık, kıyas, kıyas çeşitleri aktarılmıştır. İkinci bölümde nesne, cisim, cismanilik, nefs, bilgi ve nefsin ilişkisi, irade, nefsin irade üzerindeki etkisi anlatılmıştır. Üçüncü bölümde ise metafizik; insan - Tanrı, alem - Tanrı, hayr - şer, metafiziki bilginin imkanlılı̆̆ı, nefsin cevheriyeti, nefsin öğrettikleri, tat - keder, mutluluk - hüzün, inayet, bilgelik (Ariflik), alimliğin ötesi, ahlak eksenlerinde açiklanmıştır. Eserde zikredildiği üzere tembih bilme usulü, mantıkla karar verilen bilgidir, işaret ise mananın, metafiziğin, fiziki evrenin ötesindeki öz bilgiyi anlama yöntemidir. İşarat ve't Tenbihat, nefsin doğasını, bilincini ve işleyiş prensiplerini açıkladığı Eş Şifa eserinin bir özeti mahiyetindedir ki Eş Şifa incelenmeden İşaretler ve Tembihler'in anlaşılması mümkün değildir.

İbn Sina'nın eserleri farklı yüzyıllarda yaşamış birçok tasnifdar tarafından üç ana başlıkla sınıflandırılmıştır. İlk tasnif, İbn Sina'nın Mantıku'l Meşrikıyyin eseri için gerçekleştirilmiştir (Macit, 2006). Yazmaların izan faslı 1910 senesinde yine Mantıku'l-Meşrikıyyîn ismiyle yayımlanmıştır. Sina'nın, bu başlıkta derlenen diktelerinde felsefe, varlık, doğa, beşer ve şifa üzerine çalışmaları tasnif edilmiştir.

İkinci tasnif, İbn Sina'nın hikayeleştirerek yazmış olduğu felsefi eserleri Meşrikıyye ve Hikmetü'l-Meşrikıyye (Doğu'nun Hikmetleri) üzerine gerçekleştirilmiştir. Bedevi'nin Aristu İnde'l-Arab içerisinde bildirdiği, Kitâbü'l-İnsâf'ın günümüze ulaşan nüshaları, Şerhu Kitâbî Harfi'l Lâm, Et Ta'likât Alâ Havâşî Kitâbi'n Nefs, Şerhi Kitabi Esûlûcyâ ve El Mübahasat ismini verdiği eserleridir. Abdurrahman Bedevi, Cüzcani, Beyhaki gibi isimler aracıllğıyla haberdar olunan, aktarımlardan incelenen kaynaklardan biri olan Kitâbü'l-İnsâf'ı, Abdurrahman Bedevi, Aristu İnde'l Arab adlı kitabında bildirmiştir.

İbn Sînâ, Ebu Cafer el-Kiya ile mektup yazışmalarından birinde eserin tamamının Aristo'nun tüm kitaplarındaki notlardan ve yirmi ciltten oluştuğunu, İsfihan'ın ele geçirilmesi amacıyla Sultan Mesud'un tasallutunda büyükçe bir kısmının kaybedildiğini ifade etmiştir. (Bedevi, 1977). Kitabın bu baskında kaybolduğunu Bedevi haricinde İbn Sina'nın öğrencisi olan Cüzcani de aktarmış, Beyhaki bu beyanı Tetimmetu Sıvani'l Hikme adlı eserinde tekrarlamıştır (Çetinkaya, 2015). Eserin muhteviyatıyla alakalı bilgiyi ise İbn Ebi Useybia şu şekilde aktarmıştır: "Yirmi cilt olan kitapta, Aristoteles'in kitaplarının tümünün şerhi bulunmaktaydı ve Meşrıkiler ile Mağribiler arasındaki İnsâfa dairdi! Bu Kitap Sultan Mesud'un işgali sırasında kaybolmuştur" (İbn Ebi Usaybia, 1882). 
Üçüncü tasnif yukarıda açıklaması gerçekleştirilen İşârât ve't-Tenbihât eserinin muhteviyatına yöneliktir. İlk defa Jacques Forget tarafından yayımlanan eserin (Forget, 1892) son ilmî neşri, Nasîrüddîn-i Tûsî şerhiyle birlikte Süleyman Dünyâ tarafından gerçekleştirilmiştir (Türkiye Diyanet Vakfı, 1999). Daha sonra da bu neşre dayanılarak birçok baskısı yapılmıştır. Eserin muhteviyatını aktaran en geniş çalışma da 1925 senesinde Nallino tarafından, Filosofia Orientale od Illuminativa d'Avicenna ismiyle yayımlanan çalışmadır (Nallino, 1980). Bu tasniflerin haricinde Dimitri Gutas'ın İbn Sina'nın Mirası ismiyle yayımladığı sentezler, karşılaştırmalar ve analizler İbn Sina felsefesini anlamak açısından oldukça değerlidir.

\section{Reçetelerin Temelini Oluşturan Besinlerin Sınıflandırılması}

Reçete tasnifleri; İbn Sina şifa diktesinin 15. yy. uygulayıcısı, 15. yy. Osmanlı Mutfağı reçete çalışmalarını yürüten hekim Muhammed Bin Mahmud Şirvani'den elde edilen verilerin analiz edilmesi ve araştırmacılar tarafından günümüzde tüketilen besinlere uyarlanmasıyla gerçekleştirilmiştir. Şirvani, "Mürşid" adlı eserinde İbn Sina'dan "Şeyh", El Kanuni Fi't Tip eserinden de "Şeyh Kanunu" olarak bahsetmiş, yine "Mürşid" eserinde İbn Sina'dan alıntılarla, atıflarla şifa ve tıp yaklaşımda Sina'yı otorite olarak gördüğünü beyan etmiştir (Muhammed Bin Mahmud Şirvani, 2004). Reçetelerinin altına sağlıkla ilgili eklediği bölümleri İbn Sina'nın "Şifa" yaklaşımdan genişlettiğini beyan eden Şirvani'nin, Yemek Kitabı adlı eseri besin sınıflandırılmasında araştırmacılarla çevirisi yapılıp, kaynak olarak kullanılan ana eserdir. Eserin giriş ve son kısmı kayıp olmasına rağmen, elimizde olan giriş bölümünde Şirvani'nin şu ifadeleri yer almaktadir:

"(... Allah onlarm hepsine rıza göstersin) ve ben fakir (zengin Allah'a düşün) Muhammed Bin Mahmud Şirvani ademoğlunun yaşamda sekiz tada ihtiyaç hissettiğini gözledim. Sekiz tat; yemek, içmek, giyinmek, yuva kurmak, koklamak, temas etmek, duymak ve söylemektir. Sekiz tattan insanevladı için en önemlileri; yemek ve içmektir. Bedenin tazeliği ve diriliği insanevladının yeme - içmesine bağglıdır, ikisi olmadan bedenin tazeliği gider ölü hale gelir. Nitekim bazı iliminsanlar "Dört şey güzelliği ve nimetleri tamamlar: Kuvvetli din, faydalı ve bereketli çalışma, kuvvetli yiyecek ve temiz içecek" derler.

Allah' da şöyle buyurmuştur: "Artık, Allah'ın size rızk verdiği şeylerden helal ve temiz olarak yiyin" (Nahl, 114) Ve bir yerde de "Temiz ve helal olan şeylerden yiyin" (Mu'minun, 51) İslam'ın peygamberi olan Hz. Muhammed' in "Insanların en hayırlssl, insanlara faydalı olanıdır" buyurduğunu gördüm. Ben de yemekle, içmeği anlattığım kitabı bir giriş ve on bir kısım halinde yazdım.

İş bu kitapta ilk kısım mayhoş, ikinci kısım yoğurttan, kurutulmuş yoğurttan (keşten), sütten üretilen besinlerin, üçüncü kısım çorbaların, dördüncü kısım kalye, kavurmaların, beşinci kısım tandırda, pişirilen besinlerin, altıncı kısım mutancana vb. yemeklerin, yedinci kısım taze ve kuru balıkların, sekizinci kısım turşuların, dokuzuncu kısım acı besinlerin, onuncu kısım helvaların, on birinci kısım ise kadayıf ve benzeri tatlıların reçete ve yararlarımin anlatıldığı kısımlardır."

Teorinin ana kaynağı İbn Sina' dır, Sina'nın besin özelliklerini açıkladığı bölümle, diğer fikirlerini sentezleyerek tasnifi gerçekleştirmiştir olan 15. yy. hekimlerinden Muhammed Bin Mahmud Şirvani'dir. Şirvani' den sonra Fazlur Rahman gibi teori üzerine çalışmalar yapan araştırmacılar olmuş olsa da bu çalışmalar teoriyi geliştirmekten ziyade çeviri-aktarım şeklinde yürütülmüştür.

Şirvani'nin, İbn Sina'nın Hiltlar teorisinde (İbn Sina, 2004, 2006, 2017d) yer alan gidaların özelliklerine göre açıkladığı, besinlerin bir araya getirilme nedenleri ve beslenme iki temel başlıkta sınıflandırılmaktadır (Muhammed Bin Mahmud Şirvani, 2005):

Birincisi, hafif-ağır, sıcak-soğuk, kuru-nemli gıdalar şeklindedir. İbn-i Sina halk tarafından sıklıkla tüketilen, tercih edilen besinleri nemli-kuru, soğuk-sıcak, ağır-hafif olarak altı başlık 
altında toplamıştır (Besinlerin yapısına göre İbn-i Sina döneminde bilinmeyen fakat günümüzde tüketilen gıdalar da çalışmanın daha yararlı olabilmesi adına gruplara dahil edilmiştir);

\section{Hafif Gidalar}

Buğday: Buğday, buğdaydan üretilen un ve ekmek Anadolu, Mezopotamya beslenme diyetinde en sık tercih edilen gidalardandır. Ekmek, mayasız, az tuzla yoğurulup tandır veya sacda pişirildiğinde de vücudu nemlendiren, hafif besinlerin başında gelmektedir.

Et: Horoz, tavuk (yüklü östrojen hormonu nedeniyle erkeklere ve erkek çocuklara tavsiye edilmez), kaz, balık, piliç, oğlak, keçi, kuzu, keklik, bıldırcın, çulluk, güvercin yavrusunun ve yenilen diğer kuşların etleri. Bu başlıkta yer alabilmesi için haşlama, az tuzlu olarak ve gençlerinden tercih edilmesi gerekilen etler içinde günümüzde tüketilmeyen güvercinin bedene zararı olmaması için reçetelerde özellikle yavrusu tercih edilmiştir.

Zerzevat ve Yemişler (Sebze ve Meyveler): Sebze ve meyveler temelde nem oranı yüksek olduğundan bu grupta yer almaktadır. Kabak, salatalık, incir, kuru incir, üzüm, kuru üzüm, marul, maydanoz vb. yeşillikler, kuşkonmaz, fasulye ve bu gidalara benzer, tüketildiğinde serinletici etki sağlayan, bedeni nemlendiren, ferahlık hissi veren meyve ve sebzeler hafif - nemli gıdalar başlığı altında toplanır. Çağlalar ve çekirdekler yiyeceklerin tohumu olduğundan bedene en fayda sağlayan bitkilerdir.

Süt ve Süt Ürünleri: Yoğurt, keçi sütü, keçi sütünden üretilen peynirler, hafif süt ürünlerindendir, süt de sağılan hayvanın özelliklerini taşıdığından hayvanın hangi grupta yer aldığına dikkat edilerek tüketilmelidir.

Yumurta: Bütün yumurtalar ait olduğu familyanın özelliklerini sergilediğinden yumurta tüketiminde yumurtası yenilecek hayvanın grubuna bakılmalıdır, içeriği açısından ağır gıda sınıfına girebilecek olsa da haşlanarak tüketildiğinde örnek protein olduğundan hafif gıdalarda yer alır.

Hafif ve nemli gıdaların içinde su kesiciler (balgam uzaklaştırıcılar), mayhoşlar ve sindirimi düzenleyen, hazmı kolaylaştıran gıdalar oldukça önemlidir.

Mayhoş Gıdalar: Mayhoş gıdalar; öncesinde tüketilen besinlerin midede yumuşatılıp kolayca parçalanmasına, hazmedilmesine yardımcı olurlar; sirke, genç üzüm suyu (koruk suyu) ve nar ekşisi gibi.

Su Atıcılar (Balgam Uzaklaştırıcılar): Bu başlık altında kümelenen çoğu gıda kanı soğutan ve ateşi yükselten özellikte gidalar olduğundan tüketimdeki miktara dikkat edilmesi gerekir. Sarımsak, kekik, nane, rezene, kimyon, dereotu, maydanoz, su teresi gibi.

Hazım Rahatlatıcılar: Kategoride yer alan gidaların genel özelliği gaz yapıcı nitelikte gıdalar olmasıdır. İçerdikleri ateşin, midede hazmedilemeyen gıdaya ulaşarak sindirimi rahatlatacağ savunulmuştur. Turp, pırasa, soğan, siyah üzüm, siyah incir, karpuz, kavun, bal gibi.

\section{Bedeni Yoran (Ăğr) Gıdalar}

Tahıllardan (Özellikle Buğdaydan) Üretilen Ekmekler: Pişirim tekniği olarak içine yağ ilave edilmiş ve yağda pişirilmiş ekmekler yer alır. Ekmeğin uzun süre yoğurulması glüteni daha aktif hale getirdiğinden fazla yoğurulmuş, mayalı ekmekler, özellikle odun ateşinde büyük hacimlerle (somun gibi) pişirilenler ağır ekmekler sınıfında yer almaktadır. 
Etler: İç yağı kullanılarak hazırlanmış kebaplar, dana, sığır, inek eti, sakatatlar, kokoreç, mumbar, şırdan gibi bağırsaktan yapılmış yemekler ve büyük baş ciğeri.

Süt ve Süt Ürünleri: İnek, deve, eşek sütü gibi fazla miktarda yağ içeren sütler, bu sütlerden elde edilen yoğurt, peynir ve diğer süt ürünleri.

Çerezler: Genellikle çerezlerin çoğu bu grupta yer almaktadır ancak ısıtılma, kavrulma, tuz, bal, pekmez veya şeker ilavesi çerezleri daha da ağırlaştırır. Kestane, günümüzde çok tüketilmeyen fakat eski reçetelerde sıklıkla yer alan meşe palamudu en ağır yemişlerdendir.

\section{Sicak ve Nemli Gidalar}

Etler: Bütün etler muhteviyatları bakımından nemli olmakla beraber bedeni ısıtan etki gösterdiğinden, beden dengesinin korunabilmesi, kuruluğa neden olunmaması için hoş bir ab ile (hoşaf-et tüketiminin nedeni) tüketilmesi salık verilmiştir.

Tahillar: Buğday ve çavdar.

Zerzevat ve Meyveler: Taze nohut, karabiber, kişniş, kimyon, nane, reyhan, fesleğen, tere, roka, zerdeçal, zencefil, sahlep, muz, bük üzümü, ahududu, üzüm, böğürtlen, incir, dut, kızılcık, kuşburnu, tatlı elma, greyfurt, portakal, mandalina, turunç, şalgam, siyah çay, taze buğday, hububatların tazeleri gibi tüketildiğinde bedeni ısıtan sebze ve meyvelerdir.

Çerezler: Badem içi, fındık, ceviz, çam fıstığı.

\section{Sicak ve Kuru Gidalar}

Etler: İç yağı, yenilebilecek tüm hayvanların yaşlı olanları, evcilleştirilmemiş, etçil, vahşi hayvanlar ve akreşe (dişi tavşan).

Tahıllar: Acı bakla ve bakla kurusu bilinen en sıcak ve bedeni kurutan tahıldır.

Sebzeler ve Meyveler: Sarımsak, kereviz, yer elması, patates, havuç, turp, lahana kökü, soğan, pırasa, hardal, kırmızı acı biber, isot, yeşil acı biber, patlıcan, meyvelerden ise kahve ve kakao en bilinenidir.

Çerezler: Kestane, fıstık, yer fıstığı̆, ay çekirdeği, çedene, susam, yağlı tohumlar.

\section{Soğuk ve Nemli Gıdalar}

Tahıllar: Pirinç, yulaf, mısır, mısırdan üretileni başta olmak üzere nişasta.

Etler: Etlerin içinde soğukluk oluşturan bir et yoktur ancak hayvanların özellikle boyun bölümleri yenilen diğer yerlerine göre daha soğuktur.

Sebzeler ve Meyveler: Salatalık, limon, enginar, marul, beyaz lahana yaprakları, tatlı yeşil biber, domates, tatlı kırmızı biber (kapya), taze fasulye, bamya, semizotu, maydanoz, dereotu, sspanak, karalahana, acur, kabak, erik, kayısı, vişne, kiraz, kavun, nektar, karpuz ve şeftali.

\section{Soğuk ve Kuru Gıdalar}

Baklagiller ve Tahıllar: Yeşil mercimek, kırmızı mercimek, sarı mercimek, sarı ve siyah haşhaş, darı ve arpa. 
Etler: Genellikle hayvanların derileri diğer bölgelerine göre daha soğuk ve kuru özelliktedir.

Sebze ve Meyveler: Sonbahar ve sonrasında yetişen ekşi meyveler ve sebzeler bu kategoride daha sık yer alır, zeytin, ayva, nar, tongel (döngel), ekşi kış elması, demirhindi, börülce en bilinenleridir.

İkincisi ise mevsimlere ve mizaçlara göre tercih edilecek beslenme diyeti, bedenin, aklın, mizacın dengede kalabilmesi için nasıl beslenilmesi gerektiğidir.

\section{Beslenme Metodu}

Beslenmenin bedene şifa vermesi, hıltların dengede kalabilmesi için besinlerin hangi mevsimde, ne şekilde tüketileceği en az besin özellikleri kadar önemlidir. Beslenme metodu temelli beslenme reçeteleri; mizaçlar ve mevsimlere göre düzenlenmelidir (Muhammed Bin Mahmud Şirvani, 2005).

\section{Mizaçlara Göre Beslenme}

Giriş kısmında da belirtildiği gibi İbn-i Sina çalışmalarına göre dört hılt (sarı safra, balgam, kan, kara safra-sevda) her insanda bir diğerinden farklı içerikte bir araya gelerek kişiye özel, hususi bir denge oluşturur. Bu dengeden kaynaklanan (ruhsal, bedensel, zihinsel) tüm özelliklerinin toplamı da mizaç olarak adlandırılır (Rahman, 1997). Ahlat-1 erbaa prensibinde dört temel mizaç; demevi (kan), safravi (sarı safra sıvısı - ateş), balgami (su) ve sevdavi (sevda veya kara safra sıvısı - toprak) mizaçtır. Teoriye göre her insanda baskın olan sıvı dört mizaçtan bir üst ana mizaç oluşturmaktadır.

Demevi (Hava, Sıcak-Nemli) Mizaç: İbn-i Sina'ya göre yüksek kilolu, bedenden ziyade akılla çalışmaya müsait, daha uzun yaşama eğilimli, haz ve lezzete önem veren, soğuk seven ve duygu geçişleri hızlı olan insanlardır. Demevi mizaca sahip olanlar dengelerini korumak için tercihlerini hafif, ısıyı yükseltmeyecek, harareti azaltacak, soğuk-kuru besinlerden yana kullanmalıdır. Bu mizaç vücut ısısının hızlı artmasına eğilimli olduğundan etler ekşilerle birlikte pişirilmeli, tüketilen her katı besinin yanına muhakkak ekşi hoşab (hoşaf; hoş, güzel su), ekşi koruk suyu, sirkencubin (bal ve sirke ile yapılan bir hazmettirici) gibi bir hazmettirici eklenmeli, tatlıdan kaçınmalı ve ekseri sıvı beslenme tercih edilmelidir.

Safravi (Ateş, Sıcak - Kuru) Mizaç: Demevi mizaçla benzer özellikler göstermekle beraber tez canlı, aktif, haleti ruhiyesine göre öfke yatkınlığı veya aşırı mutluluk eğilimli, kilo düşüklüğü olan mizaçtır. Mide ve baş ağrıları yoğun görüldüğünden hazmettirici, soğuk ve nemli, meyve - sebze gibi hafif gıdalar tüketmeleri, tatlıdan, etten, baklagil ve tahıldan mümkün olduğunca uzak durmaları gerekir. Pişirme tekniği olarak da yalnızca ateş kullanılarak pişirim (tandır, fırın, köz, kızartma gibi) beden dengelerini bozacağından su ilave edilmiş buğulama, haşlama gibi teknikleri tercih etmeleri gerekir.

Balgami (Su, Soğuk - Nemli) Mizaç: Balgami mizaca sahip olanlar sakin, dingin, melankoli yatkınlı̆̆ı gösteren, zayıf, narin yapıda insanlardır. Denge sorunlarında en yoğun görülen problem romatizmadır. Bu mizaç sıcak-kuru besinler, karbonhidrat, protein tüketmeli ve etleri tatlı besinlerle beraber pişirmeleri, tatlı şerbetler, bal, pekmez gibi hararetlerini yükseltecek, enerjilerini artıracak gidaları tercih etmeleridir.

Sevdavi (Toprak, Soğuk - Kuru) Mizaç: Sevdavi mizaç, verimli, sakin, ılımlı, hüzünlü yapıdadır. Bedenleri soğuk ve kuru olduğundan sıcak-nemli besinleri, ateş ve suyun dengeli biçimde 
kullanıldığı pişirme teknikleriyle pişirilmiş yiyecekleri tercih etmeleri hılt dengeleri açısından önemlidir.

\section{Mevsimlere Göre Beslenme}

Bu bölüm İbn Sina'nın dört mevsimde sağlığın ve dengenin korunma yollarını açıkladığ Tedbirü's - Sihha Fi Fusuli'l - Erbaa ve Muhammed Bin Mahmud Şirvani'nin koruyucu hekimlik üzerine yazdığ 1 Sultaniyye adlı eserlerden elde edilen verilerle çalışılmıştır.

Yaz: Yazın hava sıcaklığı bedende kuruluğa ve hararetin yükselmesine neden olduğundan soğutucu, nemli yiyecek ve içecekler tercih edilmelidir. Yemek yemeyi azaltmak, ekşi, serin, hazmı rahatlatacak, bedendeki su miktarını artıracak yiyecekler tüketmek, baharatlardan ferahlık verenleri, ekseriyetle de itırlı bitkileri tercih etmek gereklidir. Ekmekler mayasız ve ince, etler, dolmalar, sarmalar soğukluk veren, ekşi - mayhoş meyvelerle pişirilmelidir. Güneşin yoğun olduğu yaz aylarında pişirim tekniklerinden ateş ile suyun birlikte kullanıldığı haşlama, buğulama gibi teknikler seçilmelidir. Yaz mevsiminde safranın çoğalması baş ağrısına, rehavete sebep olduğundan bu sorunun yaşanmaması için tuzdan ve yağdan kaçınmak gerekir.

Kış: Yazın tam tersi bir beslenme diyeti uygulanması gereken kış mevsiminde mizaç doğrultusunda sıcak, kuru, harareti yükseltecek, 1sitıcı besinler; etler, yumurtalar, peynirler, yağlı, tatlı, tahıllı, proteinli, baklagilli gıdalar, kurular, yemişler ve çerezler tüketilmelidir. Pişirme tekniklerinden ateşin daha yoğun kullanıldığı köz, kızartma, fırın gibi teknikler seçilmelidir. Etler, dolmalar, börekler, hamurlar, sarmalar, pilavlar tatlı baharat ve tatlı meyvelerle beraber pişirilmelidir.

Bahar: Bahar mevsimleri kış ve yazın arasında geçiş mevsimleri olduğundan ilkbaharda serinnemli-hafif, sonbaharda sıcak-nemli-ağır gıdalarla beden, dengesini yitirmeyecek biçimde desteklenmelidir. Her iki baharda da kuruyemiş, çerez yenmesi bedene zarar vereceğinden, ara dönemler az yemekle, mide dinlendirmekle ve hazmı kolaylaştıracak sıvı beslenmekle geçirilmelidir.

Yukarıda yer alan bilgilerin ışığında Hıltlara göre beslenme diyeti; ezcümle mizaci özelliklerin temel alındığı bir beslenme, sağlık, evveli başta koruyucu hekimlik diyetidir. Beşerin haleti ruhiyesine yönelik mizacının tayiniyle, içinde bulunulan mevsimin mizaçta bir dengesizliğe sebep olmaması adına mevsime uygun besinler değerlendirilir. Sonrasında besinlerin dahil olduğu sınıf bulunarak uygun besin, uygun teknikle, uygun mevsimde, uygun mizaca reçete edilir. Günümüzde de bu beslenme tekniğinin kullanılabilmesi için aynı sıra takibi ile; mizaç tayini, mevsim ve besin sınıflaması tüketilecek gıdaların reçetelendirilmesinde izlenmesi gereken yöntem olarak değerlendirilebilir.

\section{YÖNTEM}

Araştırmada nitel araştırma tekniklerinden doküman analizi tekniği kullanılmıştır. Doküman analizi, araştırılması hedeflenen olgular hakkında bilgi içeren yazılı materyallerin analizini kapsamaktadır (Karasar, 2007). Dolayısı ile araştırmada Hıltlar teorisini geliştiren ve çalışmalarını beşerin doğal, mükemmel dengesinde, en verimli haliyle var olması üzerine derinleştiren İbn Sina'nın kendisi, öğrencileri ve ekolünden gelen hekimler, düşünürler tarafından fikirlerinin ve uygulamalarının kaydedildiği, günümüzde ulaşılabilen el yazması eserler ve diğer basılı kaynaklar incelenmiş ve analiz edilmiştir. 
Kaynakların belirli kısımları, birçok farklı ülkenin kütüphanelerinde ve el yazması eser müzelerinde korunmakta olup, Türkiye'de de Ayasofya Müzesi, Konya Yazma Eserler Müzesi, Millet Kütüphanesi, İstanbul Üniversitesi Sultan Ahmet Kütüphanesi ve Süleymaniye Kütüphanesi'nde muhafaza edilmektedir. Bu incelemede veriler zikredilen kütüphane ve müzelerin arşivlerinden ve konu ile ilgili yayımlardan elde edilmiştir. Elde edilen verilerin önemli kısmı Arapça, İbranice ve Osmanlıca yazılmış olduğundan araştırmacılar tarafından bizatihi yerinde, günümüz Türkçesine çevrilerek incelenmiştir. Eserler hakkındaki bilgilere ve muhafaza edildikleri yerlere ilişkin detaylar ve analiz edilen eserler şu şekildedir;

Ayasofya Müzesi: Ayasofya Müzesi'nde İbn Sina'nın 33 numaralı kayıtta El Urcüze Fi'l Mantık eseri, 2403 numaralı kayıtta El Hidaye, En Necat ve Şifa eserlerinden nüshalar saklanmaktadır. Bu nüshalarda İlahiyyat (İlahiyat), Riyaziyyat (Matematik) ve Tabiyyat (Doğa Bilimleri) olmak üzere tasnif edilmiş üç temel bölüm mevcuttur.

İstanbul Üniversitesi Kütüphanesi: Muhammed Abdullah Eş Şucai El Farisi'nin 1487'de düzenlediği Kitabu'l Hikmeti'l Meşriki Et Tabii Tasnifu'ş Şehi'r- Reis Ebi Ali İbn Sina Rahimehullah yazma eseri 2125 numara ile ayrıca En Necat eseri 3408 kayıtla İstanbul Sultan Ahmet Kütüphanesi'nde bulunmaktadır. Yazma Eserler bölümünde 4755 numara ile kayıtlı olan El Kanun -i Fi't Tıp eserinin bir özeti sayılan El Urcuze Fi'l Mantık Risalesi Sina'nın şifa yaklaşımını açıkladığı mühim eserlerindendir.

Süleymaniye Kütüphanesi: Carullah Efendi tarafından nakledilen El işaret ve Tenbihat eseri, Süleymaniye Kütüphanesi'nde 1272 nolu belge kaydıyla yer almaktadır. El Urcuze Fi'l Mantık Risalesi'nden bir bölüm 4829 numara ile kaydedilmiştir.

Konya Yazma Eserler Müzesi: İbn-i Sinâ'nın El-Kanun Fit-Tıbb eserinin 2. cildi, Abdurrahman b. Yesevi tarafından Hicri 529'daki (miladi takvimde 1135) aktarımı Konya Yazma Eserler Müzesi, Soğuk Oda bölümünde muhafaza edilmektedir.

Millet Kütüphanesi: Muhammed Bin Mahmud Şirvani'nin Yemek Kitabı adlı eseri, Millet Kütüphanesi'nde Ali Emirî Yazmaları Bölümü'nde müteferrik (dağınık) vaziyette, 143 belge numarasıyla korunmaktadır.

\section{SONUÇ ve ÖNERILER}

Hıltlar teorisi, mikrop kaynaklı hastalıklar bulunana değin tıbbın izlemiş olduğu tedavi yöntemidir. Bu yöntemin uygulamasında cerrahi işlem gerektirmeyen tüm hastalıklar için besinler birer ilaç olarak kullanılmıştır. Besinlerin ilaç olabilmesi reçete edilebilmelerine bağlı olduğundan hekimler reçete tasnif darlığının yanı sıra aşçılık dahi yapmışlardır. Hıltlar teorisi çerçevesinde reçeteler dikkatli incelendiğinde besinlerin bir denge içerisinde, elde olan malzemeyle yemek yapmaktan çok öte bir bilinçle hazırlandığı ve tüketildiği görülmektedir.

Teorinin en görünür destekleyicilerinden cacık reçetesi yoğurt, nane, sarımsak, zeytinyağı ve salatalığın neden bir arada tüketildiğini, reçete kombine nedenlerini merak eden, araştıran yemek severler için en açıklayıcı reçetelerdendir. Reçetede beden dengesine zararlı bir tesiri olmaması adına soğuk - nemli gıdalardan salatalık ve yoğurt, sıcak - kuru, sıcak - nemli gidalardan sarımsak, zeytinyağı ve nane ile dengelenmiş, sıcak, soğuk, kuru, nemli dengesinin sağlanmasıyla cacık reçetelendirilmiştir. Yine bu prensibe bağlı olarak bahar ve yaz aylarında kayısı, vişne, erik, damla sakızı, kavunla pişirilen etlerin, dolmaların, pilavların, tatlıların, sonbahar ve kış aylarında ayva, nar, kuru üzüm, kuru yemiş, tarçın, yenibahar, karabiberle tüketildiği görülmektedir. Pilavlar, mevsimine göre kış aylarında ısıtıcı kök ve baharat, kuru meyve - yemiş şerbetleri, yaz aylarında ise çiçek ve 1tırlı bitki şerbetleri ile sunulmuş, her et 
özelliğine göre muhakkak yanında demirhindi, sirkencubin gibi hafifletici, hazmettirici içeceklerle ikram edilmiştir. Kış aylarında baklava, lokma gibi tatlılar bal ve bal şerbetiyle tatlandırılırken, unlu, kızartmalı tatlılar, helvalar tercih edilmiş, yaz aylarında ise yine helva, baklava gibi tatlllar şerbetsiz olarak, kavun, zerdali gibi meyvelerle lezzetlendirilmiş, muhteviyatında tereyağı yerine peynir, lor gibi daha hafif süt yağı içeren besinler tercih edilmiştir. Tüm yemekler ilkbahar ve yaz aylarında tereyağı - zeytinyağı ile haşlama, kısık ateşte suyunda pişirme, bastı, silkme, buğulama gibi su ilave edilerek hazırlanmış, son bahar ve kış aylarında tereyağı - iç yağı ile kızartma, közleme, fırınlama gibi susuz, direkt ateş kullanılan tekniklerle pişirilmiştir. Ekmekler ilkbahar ve yaz mevsimlerinde mayasız, ince pişirilirken, sohbahar ve kış mevsimlerinde somun başta olmak üzere tok, mayalı, ağır ve uzun pişirme yöntemleriyle hazırlanmıştır. Bu bağlamda Hıltlar teorisi, birçok reçetenin farklı minvalde çeşitlendirilmesini sağlayarak Türk Mutfağına şifanın yanı sıra zenginlik katmıştır.

Teorinin kullanılmasıyla lezzetli yemekler oluşmuş olsa da temel amaç elbette lezzet değil mizacın dengede kalmasıdır. İbn Sina'nın sık sık vurguladığı üzere kişinin verimli bir hayat yaşayabilmesi, açık bir zihne sahip olabilmesi, idrak gücünün kuvvetli kalabilmesi, var oluşu algılayarak yaşamına üretken bir insan halinde devam edebilmesi tükettiklerinin farkında olmasına ve kontrol etmesine bağlıdır. Mizacı dengede tutarak akli, zihni, bedeni dengenin sağlanabildiği, her açıdan sağlıklı, insani bir yaşamın mümkün olduğunu savunan teori, bugün birçok besini aynı anda, karıştırıp tüketen insanın bozulan dengesini ve sağlığını yeniden düzeltmede kullanılabilecek, değerli, unutulmuş, önemli bir kaynaktır. Günümüzde her yaş grubunda çoğalan hastalıklar, çocuklarda sıkça görülen hiperaktivite, odaklanamama gibi psikolojik - zihinsel sorunlar, kanser, astım, obezite ve daha birçok rahatsızlık yeme - içme diyeti ile tedavi edilebilecek durumdayken, yanlış beslenmeden kaynaklanan sorunlar ayyuka çıkmışken Hıltlar teorisine yönelik reçete tasniflerini gündeme taşımak gereklidir (Çiftçi ve diğerleri 2008; Dinler, 2009; Tahiroğlu, 2003; Özenoğlu ve Ünal, 2016). Reçete düzenlenmesi ve doğru şekillendirilmiş beslenme diyeti ile sağllğına kolaylıkla kavuşabilecek, gereksiz ilaç ve kimyasal istilasından kurtulabilecek bireyler için bu teori hayati önem mahiyetindedir. Zira her kimyasal bedende bir onarımı gerçekleştirirken aynı anda başka bir yıkıma da neden olmakta, şifa zehirde aranmaktadır.

Teorinin fayda sağlayabilecek bir diğer boyutu; günümüzde farklı deneyimler arayan, gastronomi turizmine dahil olan yerli-yabancı turistler için Ahlat-ı Erbaa yaklaşımına dayalı işletmelerin doygunluk hissi sağlamış, aynı kalıplarla hizmet sunan işletmelere göre tercih edilecek olmaları öngörüsüdür. İşletme, mekan, dizayn, mönü, bir birlik içerisinde (minyatürler, yazmaların yer aldığı panolar, hikayeler vb.) sunulduğu vakit, yemekle birlikte aktarılacak bir şifa, sağlık, beslenme kültürü olacaktır. Bu kültürde İbn-i Sina, Şirvani, saray, İstanbul, Hipokrat, Galen, dolayısıyla Bergama, Anadolu'nun sahip olduğu tarihi-kültürel değerler aktarılırken hikayenin öncesi ve sonrasını merak ettirmek turizm eğilimini artıracak bir merak yönlendirmesi, nihayetinde turizm hareketi oluşturabilecektir.

İşletmeler açısından teorinin uygulanma koşulları düşünüldüğünde üç temel problem göze çarpmaktadır; mizacı bilinemeyen misafire yemek sunumu, mevsime yönelik beslenme ve bir arada tüketilecek gıdaların misafire açıklanması. Reçetelerin profesyonel mutfaklarda, ikram edilecek, mizacı bilinmeyen misafirlere uygulanabilmesi sorunu için reçetelerin denge bozukluğu oluşturmayacak biçimde (cacıkta olduğu gibi) düzenlenmesi çözümdür ancak teorinin uygulanabilmesi için yeterli değildir. Hıltlar Teorisi veya Terapötik Gıda'yı temel alarak hizmet veren bir yiyecek - içecek işletmesinin mönü kartında yemeğin hangi mizaca uygun olduğu, hangi mevsimde tüketilebileceği açıklama şeklinde yazılırken, o gıdayla yenilebilecek besinler de birlikte tüketilmesi tavsiye edilenler şeklinde eklenebilir ve set mönü de uygulanabilir. Mevsime yönelik teori uygulamasının gerçekleştirilebilmesi için, hali hazırda çoğu 
işletme malzeme ulaşılabilirliği sağlamak nedeniyle genellikle kış ve yaz mönüsü olmak üzere iki farklı içerikle tasarlanmaktadır. Teorinin mevsime uygunluk ilkesi de bu yöntemle çözüleceğinden profesyonel mutfaklarda kolaylıkla uygulanabilecek bir beslenme prensibidir.

Ezcümle bu çalışma, geçmişin bilgeliğinin günümüze, günümüz mutfağına uyarlanmasıyla, beşerin yitirdiği dengesine kavuşarak verimli bir hayat sürmesine katkı sağlayabilmesi ve Osmanlı'dan günümüze ulaşan reçetelerin anlaşılabilmesi adına yapılmıştır. Baharatların, meyvelerin, yemişlerin, tatılıarın, çorbaların, macunların, turşuların, şerbetlerin, pilavların, etlerin, böreklerin, sebzelerin, yemeğin dili olan Hiltlar teorisi, yemek tutkusu taşıyan her bireye bir bilgi fısıldamaktadır, bilgi odur ki; yemek bir şifa yahut hastalık, mutluluk yahut elem, nefs yahut nefestir.

Sina'nın Şifa kitabından hastalık halinde beslenme önerilerinden örnekler;

"Ateşli hastalık kandan olduğundan kişi kanının fazlasını aldırmalı ve yumurtanın sarısı, sirke, hindiba yemelidir."

"Kara sevda çekenin mizacının dengeye gelebilmesi için bol sıı tüketmesi, çorba gibi sıvı - hafif gıdarla beslenmesi, güzel kokular koklayarak mutluluğunu artırması ve hamama gidip terinden arınması gerekir."

"Kişide astım - nefes darliğı mevcutsa bal, sarı incir, badem, nohut suyu, ceviz yağı, dereotu yedirilip üzerine sıcak su içirilir."

“Böbreği hasta olana süt ve ağır yemekler yasak edilmeli, karpuz çekirdeği, anason, üzüm çekirdeği yahut kereviz yedirilmelidir. Diken, gül çekirdeği, hatmi, molehiya tohumu ve gül bir dirhem ağırlğ̆ında karıştırıllp ezilir ve mayhoş, ferah bir içecekle içirilir."

"Uçuk veya mantarda tüketilen gıdalar hafifletilmeli, beden rahatlatılmalıdır."

"Okuma, anlama gü̈çї̈̆̈̈ olan sesini yükselterek okuyup bol sıoı tükettiğinde zihni açılıp tazelenir, okudukları zihnine kaydedilir."

"Yemek yağhl ise acıyla, acıysa yağhlyla; tatlıysa ekşiyle, ekşiyse tatlıyla yenilip dengelenmelidir."

"Kizartma ile haşlama, et ile balık, kurutma ile taze, et ile süt, yumurta ile et, baklagille balı tüketilmesi bedene zarar verir." (İbn Sina, 2014).

\section{KAYNAKÇA}

Akpınar, A. ve Harmancı, E. (2009). 15. yy. Anadolusundan Bir Beslenme Kuramı: Hekim Şirvani'nin Sultaniyye Adlı Eseri, Türkiye Klinikleri Endokrinoloji: 2 (3), sy. 67 - 74.

Altıntaş, H. (1985). İbn Sina Metafiziği, Ankara Üniversitesi İlahiyat Fakültesi Yayınları, Ankara, No: 177.

Anawati, G. C. (1950). Mü'ellefâtü İbn Sinnâ, Dârü'l-Maârif, Kahire, s. 26.

Arıkan, A. (2010). Tolga Eczanesi: Ecz. Murat Özdoğan'ın Türk Eczacllık Tarihi Koleksiyonu, Osmanlı Bilimi Araştırmaları: 12 (1), sy. 75 - 103.

Aristoteles. (1935). Metafizik. (Çeviren: Ülken, H. Z.), Vakit Yayınları, İstanbul.

Aristoteles. (2017). Nikomakhos'a Etik. (Çeviren: S. Babür), BilgeSu Yayıncllı, Ankara.

Arslan, A. (2008). İlkçă̆ Felsefe Tarihi, Bilgi Üniversitesi Yayınları, İstanbul, Cilt 1: 261 - 284.

Bedevi, A. (1977). Aristu İnde-l Arab, İnşirat - 1 Beydar Yayınevi, Kum, sy. 33 - 122.

Binbaşı Hüseyin Bey. (1874). Düstur'ül Edviye, Mektebi Tıbbiye Matbaası, İstanbul. 
Corbin, H. (1980). Avicenna and the Visionary Recital, trc. W.R. Trak Irving, Texas: Spring Publications, sy. $35-275$.

Corbin, H. (1986). İslam Felsefesi Tarihi, (Çeviren: Hatemi, H.), İletişim Yayınları, İstanbul.

Çelebioğlu, S. (1963). Farmakognozi Repetitorium, Çelikcilt Matbaası, İstanbul, sy. 23 - 89.

Çetinkaya, B. A. (2015). Doğudan Batıya Düşüncenin Serüveni Felsefe, Ahlak ve Kelamın Sentezi, İnsan Yayınları, İstanbul.

Çiftçi H., Akbulut G., Mercanlıgil S. (2008). Solunum Sistemi Hastalıkları ve Beslenme Tedavisi, sy. 17 - 22, T.C. Sağlık Bakanlığı Temel Sağlık Hizmetleri Genel Müdürlüğü Beslenme ve Fiziksel Aktiviteler Daire Başkanlığı, Ankara.

Daremberg, Ch. and De La Martinière Br. (1962). Hippocrate'ın ve Salerno Tip Okulu'nun Aphorismaları, (Çeviren: Uzluk, F. N.), Ankara: Ankara Tıp Fakültesi Tıp Tarihi Enstitüsü: 53.

Dağ, M. (2014). İbn Sînâ'nın Psikolojisi. İbn Sînâ Doğumunun Bininci Yıl Armağanı, Türk Tarih Kurumu, 2. Baskı, Ankara, sy. 405 - 506.

Demirhan, E. A. (1975). Mısır Çarşııı Drogları, Hüsnütabiat Matbaası, İstanbul, sy. 35 - 55.

Demirhan, E. A. (2001). Doğal İlaçlarla Geleneksel Tedaviler, Alfa Yayınları, İstanbul, sy. 23 - 456.

Dinler, G. (2009). Çocuk Kanser Hastalarında Beslenme, Güncel Pediatri, 7(1), sy. 31 - 36.

Durusoy, A. (1997). İbn Sina'nın El-Mücezü's - Să̆̌̂̀r Fi'l-Mantık Adlı Risalesi, Marmara Üniversitesi İlahiyat Fakültesi Dergisi, İstanbul, sy. 13-15.

Forget, J. (1892). Le Livre des Théorèmes et Avertissements, E.J. Brill, Leiden.

Goichon, A. M. (2004). İbn Sina Felsefesi ve Ortaçağ Avrupa'sındaki Etkileri, (Çeviren: Yakıt, İ.), Ötüken Yayınları, İstanbul.

Gutas, D. (1988). Avicenna and the Aristotle Tradition, E.J.Brill, Köln, s. 287 vd.

Gutas, D. (2010). İbn Sînâ'nın Mirası, (Çeviren: Kara, M. C.), Klasik Yayınları, İstanbul.

Hamarneh, S. (1973). Pharmacy in Medieval Islam and the History of Drug Addiction, Med History: 16 (3), sy. $226-237$.

Hipokrat. (2018). Hava, Su, Toprak, (Çeviren: Tanrıverdi, L.H.), İnönü Ünv Yayınevi, Malatya.

İbn Rüşd. (2017). Aristotales Metafizik Büyük Şerhi, (Çeviren: Macit, M.), Litera Yayıncllık, İstanbul. İbn Sina. (2009). Edviye-i Kalbiye, (Çeviren: Kilisli Rıfat Bilge), Türk Tarih Kurumu Basımevi, Ankara.

İbn Sina. (1984). El Mebde Vél Me' Ad, (Çeviren: Nurani, A.), Müessese - i Motalat - 1 İslami Danişgah - 1 Mcgilli, Tahran.

İbn Sînâ. (1978). El Mübâhasât, (Çeviren: Bedevî A., içinde Aristu İnde'l-Arab), Vekâletü'lMatbûât, Kuveyt.

İbn Sina. (2014). İbn Sina'nın Şifa Kitabı, (Çeviren: Saatçioğlu, F. ve Ukray, M.) E - Kitap, İstanbul. İbn Sînâ. (2004). Kitabu'ş-Şifâ Metafizik I, (Çeviren: Demirli, E. ve Türker, Ö.), Litera Yayınclık, İstanbul. 
İbn Sînâ. (2006). Kitabu'ş-Şifâ Mantığa Giriş, (Çeviren: Türker, Ö.) Litera Yayıncılık, İstanbul.

İbn Sînâ. (2017a) El-Kânûn Fi't-Tıbb Birinci Kitap, (Çeviren: Kahya, E.), Atatürk Kültür Merkezi Yayınları, Ankara.

İbn Sînâ. (2017b). El-Kânûn Fi't-Tıbb İkinci Kitap, (Çeviren: Kahya, E.), Atatürk Kültür Merkezi Yayınları, Ankara.

İbn Sînâ. (2017c). El-Kânûn Fi't-Tıbb Üçüncü Kitap-1, (Çeviren: Kahya, E.), Atatürk Kültür Merkezi Yayınları, Ankara.

İbn Sînâ. (2017d). El-Kânûn Fi't-Tıbb Üçüncü Kitap-2, (Çeviren: Kahya, E.), Atatürk Kültür Merkezi Yayınları, Ankara.

İbn Sina. (2004). Kitâbü'ş-Şifâ, Fizik I, (Çeviren: Macit, M. ve Özpilavcı, F.) Litera Yayıncılık, İstanbul.

İbn Ebi Usaybia. (1882). Uyûnu'l-Enbâfî Tabakâti'l-Etibbâ, Matbaatu'l Vehbiyye, Kahire, Cilt 2, s.18. Janssens, J.L. (1991). An Annotated Bibliography on Ibn Sìnā (1970-1989), Leuven University Press, Leuven.

Karasar, N. (2007). Bilimsel Araştırma Yöntemleri, Ankara: Nobel yayınları.

Kındi. (1999). Risaletü'l-Kindi fi'l-Akl, (Çeviren: Ebu Ride), Merkez - u Dirasati'l - Vahdeti'lArabiyye, Beyrut.

Kuşkonmaz, Ş. (2016). Bergama'da İki Bin Yıllık Bir Hastane ve Bir Hekim: Asklepion ve Galen. Konuralp Medical Journal: 8 (2).

Levey, M. (1966). Medical Formulary or Agrabadhin of Al - Kındi, The University of Wisconsin Press, USA, sy. 89.

Macit, M. (2002). İbn Rüşd ve Metafizik Şerhleri, MÜSBE (Basılmamış Doktora Tezi), İstanbul.

Macit, M. (2006). İbn Sînâ'da Doğa Felsefesi ve Meşşâ̂ Gelenekteki Yeri, Litera Yayıncılık, İstanbul.

Metlerr, C.C. (1947). History of Medicine, The Blakiston Company, Toronto, sy.71 - 72.

Muhammed Bin Mahmud Şirvânî. (2005). 15. Yüzyıl Osmanlı Mutfağı, (Çeviren: Argunşah, M. ve Çakır, M.) Gökkubbe Yayınları, İstanbul.

Muhammed Bin Mahmud Şirvani. (2004). Mürşid, (Çeviren: Bayat, A. H.), Atatürk Yüksek Kurumu, Atatürk Kültür Merkezi Yayını: 302, Ankara.

Nasr Seyyid Hüseyin. (2009). Üç Müslüman Bilge: İbn Sînâ, Suhreverdî, İbn-i Arab̂̂, (Çeviren: Ünal, A.), İnsan Yayınları, İstanbul, sy. 57 - 73.

Nallino. (1980). Muhâveletü'l-Müslimîn İcad Felsefeti'ş-Şarkiyye, (Çeviren: Bedevi, A.) Et Türâsü'l Yunânî Fî Hadârati'l İslâmiyye, Daru'l Kalem, Beyrut, sy. 173-217.

Nidai. (1507). Menafiün Nas (El Yazması Eser), İstanbul Tıp Fakültesi Tıp Tarihi ve Deontoloji Anabilim Dalı, Belge No: 3338, İstanbul.

Oğuz, G. (2015). Zengin Bir Mutfak: Nevşehirli Damat İbrahim Paşa'nın Bir Aylık Erzak Listesi ve Düşünürdükleri, Osmanlı Tarihi Araştırma ve Uygulama Merkezi: 37, Ankara, sy. 233.

Özenoğlu, A. ve Ünal, G. (2016). Nörogelişimsel Bozukluklarda Beslenme, Clinical and Experimental Health Sciences 6 (2), sy. 80 -85. 
Özturan, H. (2014). Akıl ve Ahlak: Aristotales ve Farabi'de Ahlakın Kaynağı, Klasik Yayınları, İstanbul.

Rahman, F. (1952). Avicenna's Psychology, Doctoral Thesis, Oxford University Press, London.

Rahman, F. (1997). İbn Sinn̂, Klasik İslam Filozofları ve Düşünceleri, (Çeviren: Bilen, O.) İnsan Yayınları, İstanbul.

Sayılı, A. (1984). İbn-i Sina Doğumunun Bininci Yıl Armağanı. T.C. Atatürk Kültür, Dil ve Tarih Yüksek Kurumu Türk Tarih Kurumu Yayınları, VII. Dizi, Türk Tarih Kurumu Basımevi, Ankara, sy. 80 .

Tahiroğlu, Y. A. (2003). Dikkat Eksikliği Hiperaktivite Bozukluğu Tanısı Alan Çocuklarm Sosyodemografik Özellikleri, Eşlik Eden Bozukluklar ve Tedavi Yaklaşımları (Yayınlanmamış Uzmanlık Tezi), Adana.

Tokatlı Hekim Mustafa. (2009). Büyük Filozof ve Tıb Üstadı İbni Sina, Şahsiyeti ve Eserleri Hakkında Tetkikler, (Çeviren: Ünal, A.), Atatürk Kültür, Dil ve Tarih Yüksek Kurumu, Türk Tarih Kurumu Yayınları, Ankara, sy. 367 - 376.

Türkiye Diyanet Vakfı. (1999). İslâm Ansiklopedisi: İbn Haldûn - İbnü'l-Cezer̂̂, Türkiye Diyanet Vakfı Yayınları, Ankara, sy. 338.

Ünver, S. (2014). İbn Sînâ Aforizması Hakkında. İbn Sînâ Doğumunun Bininci Yıl Armağanı, (Derleyen: Sayıll, A.), Türk Tarih Kurumu, Ankara, sy. 303 - 310. 